\section{A polymorphic dinucleotide repeat at the DXS7 locus}

\section{B.J.Moore, S.-P.Kwan ${ }^{1}$ and N.T.Bech-Hansen}

Department of Paediatrics, University of Calgary, 1820

Richmond Rd. S.W., Calgary, AB T2T 5C7, Canada and

${ }^{1}$ Department of Immunology, Rush Medical School,

Chicago, IL 60612-3864, USA

Source/Description: A 0.8 kb (CA)-positive TaqI sub-fragment of a cosmid hybridizing with the probe L1.28 for locus DXS7 (Xp11.4-Xp11.3, see Mandel et al., 1989), was cloned into pBluescript and sequenced. The fragment was found to contain the compound perfect repeat (Weber, 1990): $(C A C)_{5}(C A)_{18}$. PCR primers were derived from the sequence as follows:

CA strand: 5'CCACCTCACTCCAGCCTGAG 3' GT strand: 5'ACTTTGACCTTATCAAACAGGTG 3'

$\begin{array}{lll}\text { Polymorphism and Frequency: } & \\ \text { Alleles } & \text { BP } & \text { Frequency* } \\ \text { D1 } & 167 & 0.03 \\ \text { D2 } & 165 & 0.28 \\ \text { D3 } & 159 & 0.03 \\ \text { D4 } & 157 & 0.66\end{array}$

*Studied in 52 unrelated Caucasian females. $46 \%$ of these females were heterozygous. PIC $=0.52$.

Mendelian Inheritance: Co-dominant X-linked inheritance was demonstrated using four families (19 meioses).

Other Comments: PCR was carried out using a Perkin-Elmer Cetus DNA Thermal Cycler. Each $20 \mu \mathrm{l}$ reaction contained 50 $\mathrm{mM} \mathrm{KCl}, 10 \mathrm{mM}$ Tris- $\mathrm{HCl} \mathrm{pH} 8.3,1.0 \mathrm{mM} \mathrm{MgCl}, 170 \mu \mathrm{g} / \mathrm{ml}$ BSA, $0.05 \%$ Tween $20,0.05 \%$ Nonidet $\mathrm{P}-40,50 \mathrm{ng}$ genomic DNA, $0.25 \mu \mathrm{M}$ of each primer, $20 \mu \mathrm{M}$ of each of dATP, dGTP, $\mathrm{dCTP}$ and dTTP, $10 \mu \mathrm{Ci}\left[\alpha^{32} \mathrm{P}\right] \mathrm{dCTP}$ at $3000 \mathrm{Ci} / \mathrm{mmol}$ (Amersham), and 1U Taq DNA polymerase (Pharmacia). Amplification conditions were $94^{\circ} \mathrm{C} / 7 \mathrm{~min}$, , then 30 cycles of $94^{\circ} \mathrm{C} / 30 \mathrm{sec} ; 62^{\circ} \mathrm{C} / 30 \mathrm{sec} ; 72^{\circ} \mathrm{C} / 2 \mathrm{sec}$ with a final elongation step of $72^{\circ} \mathrm{C} / 7 \mathrm{~min}$. A $2 \mu \mathrm{l}$ aliquot was electrophoresed on a $8 \%$ polyacrylamide sequencing gel which was dried and exposed to Cronex 4 Daylight. film overnight.

Acknowledgements: This work was supported by grants from the RP Eye Research Foundation, the Alberta Children's Hospital Foundation, The Ian Douglas Bebensee Foundation, and March of Dimes (SPK). BJM is the recipient of NSERC and AHFMR Studentships.

References: 1) Mandel,J.-L., Willard,H.F., Nussbaum,R.L., Romeo,G., Puck,J.M. and Davies,K.E. (1989). Cytogenet. Cell Genet. 51, 384-437. 2) Weber,J.L. (1990) Genomics 7, 524-530.

\section{Two CA-dinucleotide polymorphisms at the COL4A5 (Alport syndrome) gene in Xq22}

\author{
D.F.Barker, J.Cleverly and P.R.Fain \\ Genetic Epidemiology, University of Utah Research Park, \\ Salt Lake City, UT 84108, USA
}

Source/Description: Two CA-positive Sau3A fragments were identified from clone MG-2 by Southern hybridisation.

\section{Primer Sequences: \\ 2B6-1 TAT AAT GGA AGT TAT TCA TGT AGA C \\ 2B6-3 GTG ATT CAG ATG TTA CTT AAG GAC \\ 2B20-2 GGT GCC CTT TTT AAT ACA TTT TCC \\ 2B20-4 TTA GAC AAG CTT TTA CTC CCA AGA}

Polymorphism/Frequencies: In $33 \mathrm{CEPH}$ mothers are:

$\begin{array}{rlllll}\text { Allele } & \text { bp } & \text { Frequency } & \text { Allele } & \text { bp } & \text { Frequency } \\ \text { 2B6: A1 } & 164 & .075 & \text { 2B20: B1 } & 122 & .02 \\ \text { A2 } & 162 & .44 & \text { B2 } & 120 & .80 \\ \text { A3 } & 160 & .18 & \text { B3 } & 118 & .18 \\ \text { A4 } & 158 & .09 & & & \\ \text { A5 } & 156 & .15 & & & \\ \text { A6 } & 154 & .015 & & & \\ \text { A7 } & 150 & .045 & & & \end{array}$

Observed heterozygosities are: $2 \mathrm{~B} 6,25 / 33=.76 ; 2 \mathrm{~B} 20,13 / 33$

$=.39$; combined, $26 / 33=.79$.

Mendelian Inheritance: Both markers show complete linkage to $\mathrm{X}$-linked Alport phenotype in families with an X-linked defect, with a combined LOD of 5.97 at $\theta=0$ in two such families with $2 \mathrm{~B} 6$.

Chromosomal Location: $\mathrm{Xq} 22$ is the location of the COL4A5 gene as confirmed in (3) and references therein. Genetic mapping of the 2B6 polymorphism with respect to key recombinant individuals in the CEPH families indicated a location proximal to DXS287 and distal to (DXS328, DXS265), consistent with physical localization data (3).

PCR Conditions: Amplifications in $10 \mu$ l volumes were initiated with $25 \mathrm{ng}$ of genomic DNA in reactions containing $0.5-1 \mu \mathrm{M}$

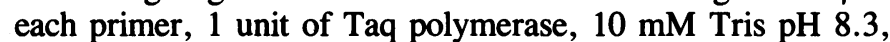
$50 \mathrm{mM} \mathrm{KCl}, 1.5 \mathrm{mM} \mathrm{MgCl} 2,200 \mu \mathrm{M}$ dNTPs except $5 \mu \mathrm{M} \mathrm{dC}$ TP plus $2.5 \mu \mathrm{Ci}$ alpha-32P-dCTP at $3000 \mathrm{Ci} / \mathrm{mmole}$. The thermal profile was 3 minutes at $94^{\circ} \mathrm{C}$, followed by 15 cycles of 90 seconds at $94^{\circ} \mathrm{C}, 120$ seconds at $55^{\circ} \mathrm{C}, 120$ seconds at $72^{\circ} \mathrm{C}$; then 15 more similar cycles with extension of the $72^{\circ} \mathrm{C}$ portion by 3 seconds per cycle.

Acknowledgements: We thank Karl Tryggvason and Jing Zhou for the COL4A5 clones. Supported by DOE DEFG02-88ER60689, NIH DK39497 and 8R01 HG-00360-03 and NCI 5 P30 CA42014-06.

References: 1) Zhou,J., Hostikka,S.L., Chow,L.T. and Tryggvason,K. (1991) Genomics 9, 1-9. 2) Litt,M. and Luty,J.A. (1989) Am. J. Hum. Genet. 44, 397-401. 3) Barker,D.F., Fain,P.R., Goldgar,D.E., Dietz-Band,J.N., Turco,A.E., Kashtan,C.E., Gregory,M.C., Tryggvason,K., Skolnick,M.H. and Atkin,C.L. (1991) Human Genetics in press. 